\title{
Corporate Image Aspect of Corporate Management in Healthcare Industry: Definition, Measurement and an Empirical Investigation
}

\author{
Serdal Gürses ${ }^{1} \&$ Kemal Can Kılıç ${ }^{1}$ \\ ${ }^{1}$ Faculty of Economics and Administrative Sciences, Department of Business Administration, Management and \\ Organization Branch, Çukurova University, Adana, Turkey \\ Correspondence: Serdal Gürses, Faculty of Economics and Administrative Sciences, Department of Business \\ Administration, Management and Organization Branch, Çukurova University, Adana, Turkey. Tel: \\ 011-90-322-232-0119. E-mail: dr.serdalgurses@gmail.com
}

Received: September 19, 2013

Accepted: October 12, 2013

Online Published: November 22, 2013

doi: 10.5539/ibr.v6n12p31

URL: http://dx.doi.org/10.5539/ibr.v6n12p31

\begin{abstract}
The concept of corporate image has increasingly been attracting interest in business and management fields, as identifying how they are perceived by the public, and re-formulating their strategies accordingly is of utmost importance for the efficient and effective executability of the business functions, enhancement of corporate performance, and for the sustainability of corporations. Specifically, in healthcare, corporate management executives are more and more aware of the importance of corporate image and its implications for their corporations' life prospects. This important concept, however, has been approached and defined by authors in multiple different fashions, and due to its largely overlapping attributes, it has also commonly been associated with other related concepts such as corporate reputation and corporate identity. In this paper, in an effort to establish an all-encompassing, clear and consistent conceptual definition for corporate image, the authors first attempt to provide a definitional statement based on a substantial theoretical research, then present a new model for capturing the corporate image for the corporations operating in the healthcare industry, and finally execute its initial application on a chain hospital through surveying 710 people in Turkey.
\end{abstract}

Keywords: corporate image, corporate management, corporate performance, corporate reputation, healthcare industry

\section{Introduction}

What would be the likelihood of a corporation, which has isolated itself from the community in which it exists, to successfully sustain its life and actualize its vision? Undoubtedly, a corporation, which is not espoused by the community it is a part of, will be unlikely to succeed in its industry. In this respect, in order for the corporations to evaluate the effectiveness of their business politics, and more generally the effectiveness of their corporate performance, the need to periodically measure how the corporations are regarded by the members of the general public arises. With this feedback, corporate management executives will be able to re-evaluate, and also in cases where it is necessary, will have the opportunity to restructure their future managerial strategies accordingly.

Empirical research testing has been constrained by using the atheoretical Fortune ratings to measure reputation (Baucus, 1995; Fryxell \& Wang, 1994; Sodeman, 1995); however, research in the area of corporate image or reputation seems to have recently drifted away from solely being dependent on the Fortune studies' reputation studies and rankings, which is centered mainly on financial aspects of large corporations. Because given the different circumstances facing many firms, it may be necessary to develop industry specific instruments. These can allow for the periodic collection of data enabling the firm to keep track of its corporate reputation and to take corrective action as necessary (Caruana \& Chircop, 2000). Following this thought process, this research is intended to make a contribution to the efforts in measuring corporate image, specifically in the healthcare industry, as most of the previous research concentrated heavily on corporations predominantly in sectors that are non-medical, and it essentially presents a comprehensive alternative method for periodic assessment of corporate image and its attributes for performance-based evaluations.

The main purpose of this research is to first perform a thorough literature search on corporate image and corporate reputation concepts, attempt to propose a definition for corporate image concept, and subsequently to develop a corporate image scale specifically designed for healthcare sector, which will be a candidate to measure 
the public's perception regarding corporate image with a marginal error rate for future research, and finally to execute its initial application on Adana branch of a private chain hospital in Turkey. With this purpose, the analytic tool proposed and field-tested by the authors provides a different point of view in terms of measuring the overall and attribute-based corporate image of companies operating in healthcare sector. It also provides insight into the strong and weak areas of the companies' certain attributes, which essentially cumulatively form the companies' overall corporate image as viewed from the perspective of the general public.

\subsection{Conceptual Framework}

In most of the corporate image and reputation literature, the two terms are often used interchangeably (Barnett \& Pollock, 2012; Chun, 2005; Whetten \& Mackey, 2002), however, authors are recently more inclined to distinguish the two terms in terms of their meanings (cf. Barnett, Jermier \& Lafferty, 2006). Thus, before proceeding to the corporate image concept and definition, we would first like to enunciate our stance in terms of whether or not corporate reputation should subsume corporate image (Fombrun \& van Riel, 1997), or the opposite (Rindell, Edvardsson \& Strandvik, 2010; Wei, 2002), without going too much into the definitional or lexicological debate regarding this topic, as taking on that approach would move us far beyond the purposes of our research. Our perspective is that corporate image and corporate reputation are conceptually intertwined, dynamically and bilaterally related (Gotsi \& Wilson, 2001) and inseparable (Balmer \& Gray, 2000) in that we follow Burke, Martin and Cooper (2011), Wartick (2002) and Williams \& Barrett (2000) that these terms can be used interchangeably. Thus, in our opinion, neither corporate image nor corporate reputation subsumes one another, as they have many exhaustive common characteristics and overlapping features that make them almost identical; therefore, in this paper both terms will be referring to the same concept and are used synonymously, and that the use of the term corporate image over corporate reputation in this paper is simply the authors' preference.

In literature, the mostly utilized corporate reputation scale by scholars is the 'Fortune's AMAC (America's Most Admired Companies) Scale, which is used in the research Fortune magazine conducts on an annual basis. Though severely criticized by some authors for focusing mainly on financial characteristics of corporations (see for instance, Dhir \& Vinen, 2005; Fombrun \& Shanley, 1990; Fryxell \& Wang, 1994), the Fortune AMAC scale has essentially formed the basis for many of the corporate image scales used in literature; however, other more comprehensive scales have been developed and utilized in literature to date.

Table 1. Summary of corporate image and reputation (and related) measures

\begin{tabular}{|c|c|c|c|}
\hline Reference & Public & Item & Dimensions \\
\hline \multicolumn{4}{|l|}{ Corporate Reputation } \\
\hline Fortune & $\begin{array}{l}\text { Senior Executives, directors and } \\
\text { financial analysts of main } \\
\text { industries in USA }\end{array}$ & 8 & $\begin{array}{l}\text { Eight dimensions: quality of management; quality of products } \\
\text { or services; innovativeness; long-term investment value; } \\
\text { financial soundness; ability to attract, develop and keep } \\
\text { talented people; responsibility to the community and the } \\
\text { environment and wise use of corporate assets }\end{array}$ \\
\hline $\begin{array}{l}\text { Fombrun and Shanley } \\
(1990)\end{array}$ & - & - & $\begin{array}{l}\text { Chronbach's Alpha of } 0.97 \text { with a single factor resulting from } \\
\text { factor analysis of Fortune data between } 1982 \text { to } 1986\end{array}$ \\
\hline Fryxell and Wang (1994) & - & - & $\begin{array}{l}\text { CFA indicates only a single performance factor plus } \\
\text { community and environment responsibility }\end{array}$ \\
\hline Brown (1995) & Industrial buyers & 6 & $\begin{array}{l}\text { Chronbach's Alpha of } 0.92 \text { and support for convergent and } \\
\text { discriminant validity from CFA }\end{array}$ \\
\hline Yoon et al. (1993) & $\begin{array}{l}\text { Corporate customers of service } \\
\text { firms }\end{array}$ & 10 & $\begin{array}{l}\text { Factor analysis of the results from the } 11 \text { companies leans } \\
\text { towards a unidimensional construct }\end{array}$ \\
\hline \multicolumn{4}{|l|}{ Corporate Image } \\
\hline $\begin{array}{l}\text { LeBlanc and Nguyen } \\
(1995)\end{array}$ & Customers of service firms & 36 & $\begin{array}{l}\text { Corporate image }-6 \text { factors: reputation of } \\
\text { directors; service offering; contract personnel; } \\
\text { corporate identity; access to service and physical environment }\end{array}$ \\
\hline
\end{tabular}


Andreassen and Lanseng Customers of service firms (1997)
8 Items assess how modem a company is; its society; the width of its portfolio; the level of customer orientation; trustworthiness; impressions from advertising and impressions from the media. A unidimensional construct with Cronbach alpha of 0.90 is indicated

\section{Store Image}

Mazursky and Jacoby Final customers of stores (1986)

Brand Image

Aaker (1991)
Customers of an automative firm
- Identifies 8 facets: merchandise, quality, merchandise of stores assortment, locational convenience, merchandise pricing, service, service in general, store atmosphere and pleasantness of shopping

20 Suggests the need to identify attributes with every application. Provides an example from the automotive industry

Source: Caruana and Chircop (2000).

It is widely accepted within the literature that evaluating corporate image based on stakeholders, Chief Executive Officers, executives, and financial managers' point of view is adequate to rank the companies in a certain industry in terms of their (financial) performances. Corporate reputation studies in Turkey have followed the same pattern, that is, a prestigious business magazine called "Capital" has been evaluating, tracking and publishing the corporate reputation of Turkish corporations since 2000, in a similar fashion Fortune does it, in the form of 'the most admired companies list'. Although most of the corporate image or reputation researches center around the relationship between corporate financial performance and corporate image as it is perceived by the top managers or executives, we believe that in order to see the big and the true picture about corporate image and/or performances, the end-users', in other words the customers', point of view should rather be evaluated extensively. Because the truth is this: if the customers become alienated from a corporation for one reason or another, the executives' or top managers' point of view becomes a null point at that time and an inevitable downward spiral sets off for that corporation. Therefore, in our research of trying to measure corporate image, we touched the heart of the issue, that is, we gathered the most valuable data which is the perception of the (potential) everyday customers of the subject healthcare facility.

\subsection{Corporate Image: Concept and Definition}

Image, in terms of corporations, refers to how stakeholders perceive and interpret the ways in which an organization manifests itself (Melewar, 2003; Hatch \& Schultz, 1997), in other words, how others see organizations (Chun, 2005) or what comes to mind when one hears or sees the logo of a corporation (Gray \& Balmer, 1998) and make sense of the activities they perform. Balmer and Gray (2000) similarly emphasize the external aspects of corporate image and state that "corporate image is the immediate mental picture that individuals or individual stakeholder groups have of an organization (p. 260), and in the same vein, Bromley (1993) proposes that image is the summary of the impressions or perceptions held by external stakeholders. When carefully reviewing these definitions, one can easily notice that in these definitions, only the perception of the recipient of the image is considered; however, in contrast, Whetten and Mackey (2002) emphasize the image maker's role in terms of how these perceptions are created or manipulated and state that image is the way organization consistently reflects itself in terms of how they would like to be visualized and defined corporate image as "what organizational agents want their external stakeholders to understand is most central, enduring, and distinctive about their organization", and in the same vein, Whetten, Lewis and Mischel (1992) later defined image as the way organizational elites would like outsiders to see the organization. Alvesson and Berg (1992) added that companies build a corporate image in order to increase the organization's attractiveness to customers. These definitions and explanations emphasize the sensory, perception and judgmental aspects of the image, but in here the image is induced by the corporation and thus is formed through various corporate behaviors, which was defined as "fabrication of public impressions" by Bernstein (1984), in order to mold public opinion or judgment in favor of the corporation. Dutton and Dukerich (1991) bring a different perspective by arguing that there are two key organizational images: the first image is what the member believes is distinctive, central, and enduring about the organization, which is defined as perceived organizational identity (in other words, 'in my opinion, my corporation possesses these distinct characteristics'). The second image is what a member believes outsiders think about the organization (also clearly emphasized in Chun, 2005), which is called the construed 
external image (see also Dutton, Dukerich \& Harquail, 1994) (in other words, 'in my opinion, my corporation is probably perceived this way'). Berg (1985) fills the gap by stating that the corporate image is "the holistic and vivid impression of a company, held in common by a group and expressing and orienting their basic feelings and attitudes towards the company, which is further supported by the statement that image is what customers believe or feel about the company from their experiences and observation (Bernstein, 1984). Berg (1985) and Bernstein (1984) take into consideration the external audiences' view in terms of how they associate themselves with the corporations.

Based on our literature review, we can conclude by stating that there are five principal aspects of corporate image: (a) perceived identity; in other words, what members think about how their organizations are distinctly characterized (Dutton \& Dukerich, 1991); (b) construed image; what members think outsiders think about their organization (Dutton et al., 1994; Dutton \& Dukerich, 1991), (c) projected image; what members present or project about their organization to influence how others think about the organization (Alvesson \& Berg, 1992; Bernstein, 1984; Whetten et al., 1992, Whetten \& Mackey, 2002), (d) perceived image; what outsiders think about an organization (Berg, 1985; Bromley, 1993; Chun, 2005; Gray \& Balmer, 1998), and finally (e) espoused image; how members of the public associate themselves with the image of the organization (Berg, 1985; Bernstein, 1984). In summary, corporate image is the mental map that constituencies have about the organization (Belasen, 2008). In line with the aforementioned sensory, perception, and judgmental aspects of corporate image and also in light of the definitions and explanations thus far, our own definition of the corporate image is, 'the composition of all the information people obtain and subconsciously reserve about an organization during a specific timeframe, which cumulatively culminates in an evaluative perceptional favorable or unfavorable judgment, using all the communication resources available to them'.

\subsection{Why Corporate Image is Important Specifically in Healthcare Industry}

In industries where competition is tough, periodic evaluation of general performances and success ratios of corporations against their rivals has been increasingly receiving attention in the current era of ever-growing regional and global competition. However, the need to evaluate general performances and success ratios of corporations, to which the degree of importance ascribed will vary when evaluated sectorally, and when considered based on the industry the corporation is in, is of great importance specifically for the corporations operating in the service sector. As stated by Fombrun (1996) "questions of reputation are of particular concern to knowledge-based institutions like consulting firms, law firms, investment banks, hospitals, and universities; their most valuable assets - the services they provide - are largely intangible. Economists call the services of these groups 'credence goods'-goods that are bought on faith, that is to say, on reputation". Weigelt and Camerer (1988) further added that "reputation play a strategically important role in service markets because, like experience goods, the pre-purchase evaluation of service quality is vague and partial (e.g., law, medicine, accounting, investment services). The professional service firms constitute the intellectual industry (Scott, 1998) whose primary assets are their professional workforce, outputs of whom are intangible and highly complex, the fact of which makes them distinct ... this distinctiveness makes the clients dependent on them, the case of which elevates organizational reputation important; hence, in order to succeed, service firms must generate superior reputation (Greenwood, Li, Prakash \& Deephouse, 2005).

But how do the corporations create a favorable image or reputation on the public, so that they secure a firm position in their industry and their products and services are preferred more than the others in the same sector? Specifically, in the healthcare industry, which operates in the service industry, the quality and reliability of healthcare services rendered become integrated with the name of the corporation. What we mean here is that the projection of the image of the corporation on the public for service firms and, for instance, for production firms will differ in many ways, as professional service firms are substantially different from ... traditional manufacturing firms (Lowendahl, 2000); hence applying theories from other forms of organizations (e.g., manufacturing) is not only inapplicable ... but may be dangerously wrong (Maister, 1993). The fact that the services rendered in healthcare sector are intangible - and thus encoded with complex knowledge (Greenwood et al., 2005) - in nature essentially integrates the name of the corporation with the services it provides. In this respect, the positive perception of corporate name by the public has a great importance in terms of generating a favorable corporate image. Consequently, in our opinion, the corporations operating in the healthcare sector which provide quality and reliable services will gain a favorable corporate name, which in turn will have a big effect in establishing a positive corporate image on the members of the public, the state of which will culminate in overall corporate success. 


\section{Method}

\subsection{Stages of Research}

It is commonly agreed upon by scholars that there is a need for scale development to be preceded by, and rooted in, a sound conceptual specification of the construct being scaled (Churchill, 1979; Peter, 1981). Thus, before attempting to study or contribute to a specific area of research, a sound theoretical structural frame needs establishment. This theoretical blueprint typically encompasses phases usually initiating at theoretical background and culminating in the results of the study where interpretations of what the entire study set out to accomplish is housed.

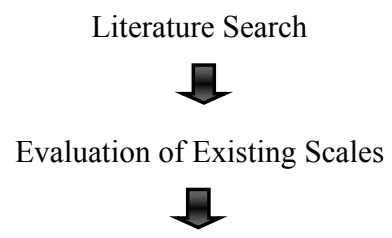

Development of a Healthcare Sector-Specific Corporate Image Scale

Application of the Scale

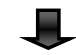

Reliability and Validity Testing

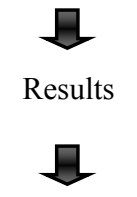

Discussion

Figure 1. Phases of the research

With this in mind, in order to successfully carry out our research, we first conducted a literature review on the corporate image, corporate reputation and related concepts. To gain an understanding of the developments occurring in the area of subject, and to form a good knowledge base, we then proceeded to review articles specifically attempting to measure corporate image and corporate reputation constructs. After gaining insight into the area of research, in collaboration with the healthcare industry specialist and the scholars whose area of interests include corporate image and corporate reputation, the authors attempted to establish a new corporate image scale designed specifically for healthcare industry. Following this stage, in order to assess the reliability and validity of the scale developed, the authors conducted a pilot survey study consisting of 50 respondents, followed by the main survey study consisting of 710 respondents. The results of both the pilot and the main survey studies revealed satisfactory reliability and validity of the scale; however, the factor analysis of only the main survey study was reported in this research due to sample size limitations of the pilot survey study. Having confirmed the reliability and validity of the scale during the pilot survey study, the authors moved to the accomplishment of the main field study, followed by the data analysis of the results. Finally, in the last phase, the discussion, the authors stated their inferences and interpretations regarding what they set out to accomplish. Overall, the authors completed the entire research, which consisted of 7 intensive phases, in a total of 12 months.

\subsection{Research Area and Subject Healthcare Facility Characteristics}

We conducted this research on a private healthcare facility which is situated in the city of Adana, Turkey. Adana is located in south of Turkey, which has a population of 2,108,805 according to the Turkish Statistical Institute, and is ranked as the fifth largest city in Turkey based on the population figures. The healthcare facility, the subject of this research, is a Joint Commission International-accredited leading healthcare services provider and a chain hospital in Turkey with a total employee population of approximately 30,000 . 


\subsection{Instrument Development and Application Methods}

The corporate reputation scale used by Fortune magazine, which mainly rates high-scale companies on eight attributes of reputation (Dhir \& Vinen, 2005), is devised more towards measuring companies' reputations, perceived within their sector by executives, from a macro perspective. However, as Fombrun and Shanley (1990) pointed out, a theoretical articulation of reputation as a construct should anticipate the multiple economic and non-economic criteria different constituents are likely to apply in assessing firms. From this point of view, the reputation scale Fortune uses is very important and beneficial, but use of this scale, as it is, is not optimal for all of the industries. Hence there exists a need for development of industry or sector-based scales towards measuring the image or reputation of the corporations, the fact of which urged the authors to attempt to develop a corporate image measurement instrument designed specifically for the healthcare industry. With this aim, after thoroughly reviewing the related literature and the general dynamics of the healthcare industry being investigated, the authors first generated an item pool potentially representing various aspects of the corporate image attributes. The item pool the authors composed was also based primarily on the Fortune magazine's eight attributes; however, the authors only utilized five of those eight attributes in the item pool and left out the 'long-term investment value', 'use of corporate assets' and 'financial soundness attributes', as they believed these attributes would not add value to the result of the analysis due to the fact that the general population was being surveyed, and incorporated additional items towards measuring the 'positive perception of corporate name' attribute to the scale, following discussions held amongst the researchers, subject healthcare facility's executive leadership board and healthcare industry and academic experts (in accordance with the nature of the research). This process resulted in generation of twenty items. After applying further and final refinements to the instrument, resulting from the academic advice and contributions of the experts in the related field, the instrument was condensed to fourteen items.

Table 2. Corporate image scale structure

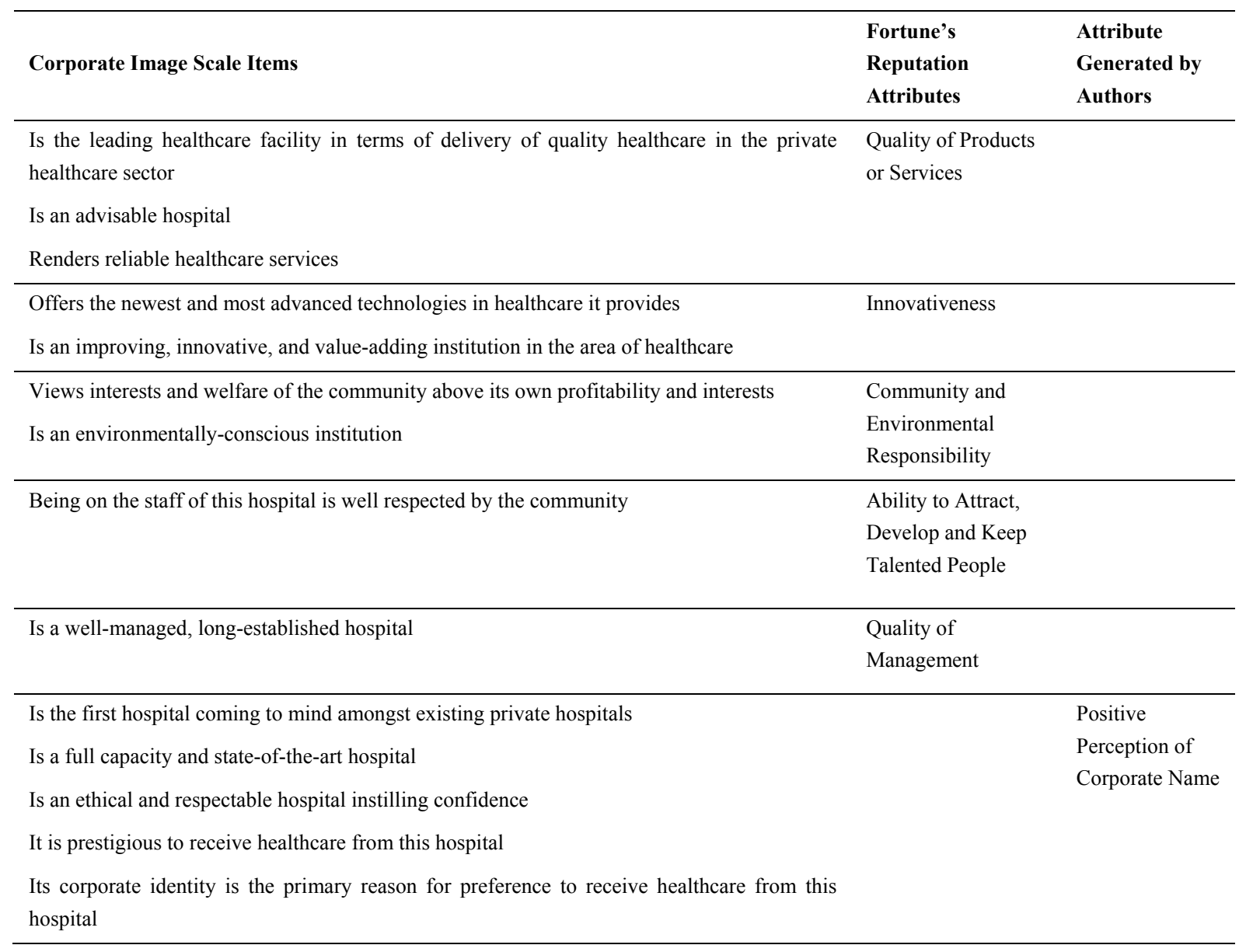


Each one of the items contained in the scale contributes to the cumulative measuring of the corporate image of the healthcare facility under study. Hence, all of the items are designed to collectively measure the corporate image. Since averaging a set of ranks (attributes' respective rankings) is problematic (Bromley, 2002), an Overall Reputation Score (ORS) is calculated following a different methodology than Fortune employed. In order to reach an overall reputation score, instead of averaging the averages of the attribute rankings, the authors calculated the average of the overall scores respondents provided on 5-point Likert scales. Every single attribute listed can also be evaluated singularly affording researchers and the healthcare facility specialists the ability to perform a more extensive analysis on the performance of the corporations in each of the six attributes, all of which collectively contribute to the establishment of corporate image. This practice should not be viewed as dimensionalizing the scale; rather it should be viewed as a more in-depth analysis into the weights each of the attribute possesses in the generation of the ORS. The fourteen-item instrument was subjected to a pilot testing through administration of it to a simple random sampling of 50 respondents recruited from the list of suppliers of the healthcare facility. The reliability and validity tests conducted on the pilot study revealed that the results were far greater than the accepted levels. We conducted a factor analysis on the pilot survey data, which revealed a unidimensional factor scale. Although pilot survey study factor analysis reflected a unidimensional scale, the researchers were not totally satisfied - due to the smallness of the sample size - since it is comforting to have at least 300 cases for factor analysis (Tabachnick \& Fidell, 2007) - therefore, researchers decided to conduct a comprehensive factor analysis on the main research sample to further validate the dimensionality of the scale, the details of which will be discussed in the results section.

In order to gain understanding or the characteristics of the sample surveyed, a demographics questionnaire was also developed to collect information on sex, age, profession, and education level of the respondents. Consequently, the researchers organized the survey instruments in two questionnaires; namely, a "Corporate Image Scale", which focuses on measurement of a corporate image, from a micro perspective, that is, the instrument aims to measure the corporate image of the institutions operating in the healthcare industry as they are perceived by the general public; and a "Demographics Questionnaire", which aims to gather data regarding the characteristics of the sample surveyed. The researchers developed both instruments in a span of four months.

In the results section of the research, we evaluated the scale as a whole to determine an overall corporate image value, and then subsequently assessed the healthcare facility's performance based on the attributes of the corporate image scale. In order for the respondents to indicate their agreement or disagreement with the statements on the items in the scale, we used a five-point Likert scale and assigned values ranging from (1) strongly disagree to (5) strongly agree. In order to reach an overall corporate image score, we calculated the arithmetic mean of the responses given to all of the fourteen items of the scale. We then converted this mean into a percentage through dividing the resulting value by five, as the Likert scale ranged from 1 to 5 . We applied the same methodology to reach attribute-based performance level scores. All statistical analyses in our research were conducted at the 0.05 level of significance.

\subsection{Sampling Methodology and Survey Organization}

For this study, a probability sampling utilizing cluster sampling method was used. The main reason for utilization of this method was the geographical area, in which the research was being conducted, was considerably wide and spread out, the fact of which would make it difficult for the researchers to administer this research financially and logistically. With this in mind, the researchers first divided the city in six main regional districts, within which four zones, which were logistically convenient for field teams to operate, were later randomly selected. Later, four street blocks were randomly selected out of the four zones identified. While selecting these four random street blocks, however, the objective was to make the overall sample representative and descriptive of the unequal distribution of the population across regional areas. Thus, great care was taken by the authors ensuring heterogeneity of the units within and amongst the clusters in terms of socio-economic and socio-cultural aspects of the populations while determining which zones and street blocks to focus on. Data collection and entry phase took place over a 2-month period, during which enumerators conducted self-administered surveys on the units of the clusters. The data collection team was composed of 20 members, all of whom underwent a pre-screening and a thorough training before they were assigned to their respective zones and street blocks. Each team had a data entry operator whose assignment was to ensure that data was collected and simultaneously captured into the computer. Completed questionnaires received from the field were entered into a Microsoft Excel 2007 database in an exclusive survey room. After taken into consideration the unit non-response and item non-response numbers and ratios, 710 of the 800 questionnaires returned were determined to be complete and usable resulting in a response rate of $89 \%$.

In terms of reaching an accepted level of sample size, the small sample technique (Krejcie \& Morgan, 1970) was 
adopted and 384 units were found to be the appropriate sample size for the population of 2,108,805, which is the total population of the city under study. However, since the general recommendation in terms of how large the sample should be is: the larger, the better (Pallant, 2010), the researchers' aim was to recruit at least double the size of the acceptable number of the sample size, and as a result, 710 completed surveys were collected and served as the field data for this research.

\section{Results}

\subsection{Demographic Characteristics of Sample}

We reached our probability sample size subjects through direct contact (face-to-face), and the respondents completed the surveys on the spot. $53 \%$ of the respondents were male and $47 \%$ of the respondents were female. $35 \%$ of the respondents were within $31-40$ age range, $31 \%$ were within $21-30$ age range, $22 \%$ were within 41-50 age range and the rest of the $12 \%$ were above 51 years of age. $51 \%$ of the respondents held a university degree and the rest (49\%) held a high school diploma or a lower level of education. $50 \%$ of the respondents were private sector employees, $26 \%$ of them were public servants, $12 \%$ of them were entrepreneurs and the rest of the $12 \%$ were retired or in the 'other' category.

\subsection{Psychometric Properties of the Corporate Image Scale}

In this phase of the research analysis, the authors performed data analysis assessing the psychometric properties of the corporate image instrument encompassing descriptive statistics (item mean and variance), reliability analysis (internal consistency), item analyses (corrected item - total correlations) and an exploratory factor analysis (principle component analysis (PCA)). In terms of reliability analysis, Cronbach's alpha coefficient was computed to assess (a) whether the respondents rated the subject healthcare's corporate image performance consistently, and (b) whether all item scores contributed to measuring a common construct. Item analysis was performed to identify whether the score of each item was related to the total scale score of the group of items. Factor analysis was performed to identify each item's dimensionality and the overall factor structure of all the items within the instrument.

\subsubsection{Reliability Analysis}

We tested the internal consistency of the entire scale using Cronbach's alpha statistics. Ideally, the Cronbach's alpha coefficient of a scale should be above 7 (Nunnally, 1978; DeVellis, 2003). The result of Cronbach's alpha coefficient was 0.935 , which indicated high level of internal consistency, i.e., the items that make up the scale are all measuring the same underlying attribute (Pallant, 2010) of the items in the scale. The main survey study Cronbach's alpha showed an increase of 0.002 when compared to the pilot survey study alpha coefficient of 0.933 , which further reinforced the construct reliability of the instrument.

\subsubsection{Item Analysis}

A descriptive statistics employed on all items in the scale revealed all items were significantly contributing to the measurement of corporate image construct, that is, each item exhibited corrected item-total correlations of 0.5 or above (the smallest value was 0.576 ) and squared multiple correlations of 0.37 or above (the smallest value was 0.373). Being completely parallel to the pilot study item analysis results, these findings reassured the authors of the fact that all items needed to be retained in the scale without a need for exclusion or revision. These findings essentially meant that individual item scores and all other item scores were concomitant; in other words, when the individual items scored high, the instrument's collective score should also be high.

Table 3. Item-total statistics of corporate image scale

\begin{tabular}{lccccc}
\hline Item & $\begin{array}{l}\text { Scale Mean } \\
\text { if Item } \\
\text { Deleted }\end{array}$ & $\begin{array}{l}\text { Scale } \\
\text { Variance if } \\
\text { Item Deleted }\end{array}$ & $\begin{array}{l}\text { Corrected } \\
\text { Item-Total } \\
\text { Correlation }\end{array}$ & $\begin{array}{l}\text { Square } \\
\text { Multiple } \\
\text { Correlation }\end{array}$ & $\begin{array}{l}\text { Cronbach's } \\
\text { Alpha if Item } \\
\text { Deleted }\end{array}$ \\
\hline $\begin{array}{l}\text { 1. Is the first hospital coming to mind amongst } \\
\text { existing private hospitals }\end{array}$ & 49.73 & 70.311 & 0.621 & 0.455 & 0.933 \\
$\begin{array}{l}\text { 2. Is a full capacity and state-of-the-art hospital } \\
\text { 3. Is an ethical and respectable hospital instilling } \\
\text { confidence }\end{array}$ & 49.49 & 72.843 & 0.688 & 0.569 & 0.930 \\
\hline
\end{tabular}




$\begin{aligned} & \text { 4. It is prestigious to receive healthcare from this } \\ & \text { hospital }\end{aligned}$
$\begin{aligned} & \text { 5. Its corporate identity is the primary reason for } \\ & \text { preference to receive healthcare from this hospital }\end{aligned}$
$\begin{aligned} & \text { 6. Is the leading healthcare facility in terms of } \\ & \text { delivery of quality healthcare in the private } \\ & \text { healthcare sector }\end{aligned}$
$\begin{aligned} & \text { 7. Is an advisable hospital } \\ & \text { 8. Renders reliable healthcare services }\end{aligned}$

Cronbach's Alpha $=0.935$

All of the values in 'Cronbach's alpha if item deleted' column appear to be less than the original Cronbach's alpha coefficient of 0.935 , which means that deletion of any of the items will not increase the alpha coefficient; on the contrary, removal of any of the items will entail considerable loss in composite reliability of the instrument. This further reinforces the existence of intercorrelations amongst the items and that all of the items collectively and affirmatively contribute to the consistency of measuring power of the instrument.

\subsubsection{Exploratory Factor Analysis}

In this part, an exploratory factor analysis was performed to confirm the dimensions of the concept that has been operationally defined, as well as to indicate which of the items were most appropriate for each dimension (Hair, Anderson, Tatham \& Black, 1998). We assessed the construct validity by conducting a principal component analysis procedure which contained the assessment of the suitability of the data for factor analysis, factor extraction and interpretation steps as suggested by Pallant (2010). In terms of the suitability of the data, we examined the sample size and the strength of relationship among the items. The issue of what is an appropriate sample size for a factor analysis has been an ongoing debate amongst scholars. In this respect, while Nunnally (1978) recommends a 10 to 1 ratio, Tabachnick and Fidell (2007) suggest five cases for each item; but they also state the it is "comforting to have at least 300 cases for a factor analysis". Gorsuch (1983) also stated that there should be at least 5 participants per variable and that a sample size of at least 200 is preferred. Streiner (1994) sided with the 5 to 1 ratio, provided that there were 100 participants in the sample with the caveat that if sample size is less than 100 , then a 10 to 1 ratio should be adopted. The fact that the instrument authors developed possesses 14 items and the sample size surveyed is 710 satisfies all of the aforementioned conditions set forth by the scholars, specifically in that (a) it is more than the 300 lower bound sample size comfort zone as suggested by Tabachnick and Fidell (2007) and (b) it is more than the sample size computed utilizing the 10 to 1 ratio as suggested by Nunnally (1978). In terms of the strength of inter-correlations amongst the items, Tabachnick and Fidell (2007) recommend evaluation of the correlations matrix for evidence of coefficients greater than 0.3 . If majority of the correlations fall below this level, a factor analysis may not be appropriate. In this respect, our findings suggest that all of the items contained in our instrument surpass this threshold, which validates the strength of relationship amongst the items (see Table 3). In order to assess factorability of the data, we performed the Kaiser-Meyer-Olkin (KMO) measure of sampling adequacy (Kaiser, 1974), and Bartlett's test of sphericity (Bartlett, 1954). Bartlett's test of sphericity should be significant $(\mathrm{p}<.05)$ for the factor analysis to be considered appropriate. The KMO index ranges from 0 to 1 , with .6 suggested as the minimum value for a good factor 
analysis (Tabachnick \& Fidell, 2007). Computation of both tests displayed satisfactory results. KMO value was 0.952 , which is well over the accepted minimum value of 0.6 and Bartlett's value was also statistically significant $\left(\mathrm{X}^{2}=6052.88, \mathrm{p}=0.00\right)$, which affirmatively confirmed that a factor analysis could be conducted.

Principal component analysis revealed the presence of only one component (factor) with its eigenvalue exceeding 1; the eigenvalue break criterion reflected that our scale could be used as a one-factor structure (eigenvalue: 7.759), which explained 55.4\% of the total variance. This finding is line with the Streiner's (1994) suggestion that in a factor analysis, factor(s) should explain at least $50 \%$ of the total variance. An inspection of the scree plot revealed a clear break after the first component, which further confirmed the unidimensionality of the scale.

Table 4. Factor matrix of corporate image scale

\begin{tabular}{lll}
\hline \multicolumn{1}{c}{ Item } & Factor Load & $\mathbf{h}^{2}$ \\
\hline 6. Is the leading healthcare facility in terms of delivery of quality healthcare in the private healthcare sector & 0.810 & 0.656 \\
8. Renders reliable healthcare services & 0.796 & 0.633 \\
3. Is an ethical and respectable hospital instilling confidence & 0.796 & 0.551 \\
10. Is an improving, innovative, and value-adding institution in the area of healthcare & 0.779 & 0.606 \\
4. It is prestigious to receive healthcare from this hospital & 0.776 & 0.605 \\
7. Is an advisable hospital & 0.774 & 0.602 \\
9. Offers the newest and most advanced technologies in healthcare it provides & 0.765 & 0.599 \\
5. Its corporate identity is the primary reason for preference to receive healthcare from this hospital & 0.743 \\
2. Is a full capacity and state-of-the-art hospital & 0.719 & 0.586 \\
11. Is a well-managed, long-established hospital & 0.691 & 0.517 \\
12. Views interests and welfare of the community above its own profitability and interests & 0.673 \\
1. Is the first hospital coming to mind amongst existing private hospitals & 0.672 & 0.453 \\
13. Is an environmentally-conscious institution & 0.624 & 0.451 \\
14. Being on the staff of this hospital is well respected by the community & 0.389 \\
\hline
\end{tabular}

N: $710 ; h^{2}$ : Communality.

In exploratory analyses, factor loadings are generally considered to be meaningful when they exceed .30 or .40 (Floyd \& Widaman, 1995). The factor analysis result (Table 4), in which a cut-off for statistical significance of the factor loadings of 0.1 was used and no cross-loading of items were identified, reflects that the 14 corporate image scale items are measuring one common factor. Factor loadings of each item to the common factor are substantially high, ranging from 0.62 to 0.81 . Communalities $\left(\mathrm{h}^{2}\right)$ give information about how much of the variance in each item is explained and low values, e.g., less than 0.3 , could indicate that the item does not fit well with the other items in its component (Pallant, 2010). Communality values ranged from 0.38 to 0.65 , reflecting all items fit well with the other items in the common factor.

\subsection{Corporate Image Scores}

In order to reach an overall corporate image score, we conducted a descriptive statistics test on the 14 attributes of the scale, and reached a mean value of $3.8318(\mathrm{SD}=0.64748)$. We further interpreted this result in terms of a percentage, through dividing it by the highest number on our Likert scale (5), and concluded that it indicated a $77 \%$ positive overall corporate image score for this healthcare facility. The results were also evaluated at the attribute level of the scale.

Results of the attribute-based analysis revealed that the respondents viewed the "quality of healthcare services provided' $(M=3.9831, S D=0.73019)$ attribute of the scale as the most effective and the 'corporate social and environmental responsibility' $(M=3.4063, S D=0.79404)$ attribute as the least effective attributes of this healthcare facility. 
Table 5. Descriptive statistics of corporate image scale attributes

\begin{tabular}{llll}
\hline Attribute & Mean & Std. Deviation & Percentage of Favorableness \\
\hline 1. Quality of the healthcare services provided & 3.9831 & 0.73019 & $80 \%$ \\
2. Positive perception of the corporate name & 3.9510 & 0.73714 & $79 \%$ \\
3. Innovative efforts of the corporation & 3.8866 & 0.74036 & $78 \%$ \\
4. Well-managed and long-established corporation & 3.87 & 0.844 & $77 \%$ \\
5. Attractiveness of employment & 3.49 & 0.983 & $70 \%$ \\
6. Corporate social and environmental responsibility & 3.4063 & 0.79404 & $68 \%$ \\
\hline
\end{tabular}

\subsection{Investigation of Relationships between the Demographic and Attribute-Level Statistics}

In this part of the research, we mainly focused on whether or not any of the demographic aspect of the subjects had any effect on the formation of the mean values obtained on the attributes of the corporate image scale. For this purpose, first of all, we conducted an independent samples t-test to investigate the relationship between the gender demographic and the attributes of the scale, and the results revealed that there was no significant difference between the answers given by the males $(M=3.8226, S D=0.66239)$ and females $(M=3.8423, S D=$ $0.63092), t(708)=0.405, p=0.686$. We conducted a one-way ANOVA test to measure whether or not there was a relationship between the age demographic and the attributes of the scale, and the results revealed that there was no significant difference between the answers given amongst the age groups, $F(4,705)=0.340, p=0.851$. We also conducted a one-way ANOVA test to measure whether or not there was a relationship between the education demographic and the attributes of the scale, and the results revealed that there was no significant difference between the answers given amongst the educational groups, $F(5,704)=0.467, p=0.801$. We further conducted a one-way ANOVA test to measure whether or not there was a relationship between the profession demographic and the attributes of the scale. The results revealed that there was no significant difference between the answers given amongst the profession groups, $F(4,705)=1.949, p=0.101$.

\section{Discussion}

In this empirical research, the authors analyzed the data collected from 710 randomly-selected subjects in order to identify and explain the perceived corporate image of a private healthcare facility located in the city of Adana, Turkey, using the corporate image scale the authors created specifically for the corporations operating in the healthcare industry. The exploratory research authors performed in this article mainly aimed to produce a robust and psychometrically sound measure of corporate image, whose construct validity and reliability were supported by the statistical analyses executed on the data collected for this research. The principal component analysis performed on the fourteen-item scale revealed a unidimensional instrument with all items loading on a single factor, and thus measuring a common construct. All items appeared to be highly correlated with the overall corporate image rating. The research also aimed to make a contribution to the lexicological aspect of corporate image by providing a definition for corporate image concept, after a thorough literature review.

Results of the study indicated that the subject healthcare facility was favorably regarded by the public in general, with an overall corporate image score percentage of $77 \%$ and further statistical analyses revealed that none of the demographic aspects of the respondents had any effect on the formation of the attribute-level mean scores. In order to understand the underlying dynamics contributing to this percentage, however, a performance-based analysis was needed. In this respect, evaluation of the score percentages of the inherent attributes of the corporate image construct revealed that the general public viewed the 'quality of healthcare services provided' attribute of this healthcare facility as being the most effective of the rest of the corporate image attributes (80\%). This finding is in line with the fact that the importance of the concept of quality to firms and consumers is unequivocal (Parasuraman, Zeithaml \& Berry, 1985), as it has strategic implications such as capturing a bigger market share, obtaining a bigger return on investment (Anderson \& Zeithaml, 1984; Phillips, Chang \& Buzzell, 1983 ) as well as lowering cost and improving productivity (Garvin, 1983). Second most favorable public perception surfaced in the results was the 'positive perception of the corporate name' (79\%). Considering the fact that companies successful enough to establish a respected corporate or brand name will add value to their products by reducing uncertainty in the minds of their customers, retailers and distributors (Balmer \& Gray, 1999), and a positively perceived corporate name essentially affords them the ability to charge premium prices 
(Beatty, 1989; Krishnan \& Schauer, 2000), makes this finding more meaningful as possessing a favorable corporate name is instrumental in creation of a positive corporate image, specifically for corporations in healthcare industry. The third most favorable public perception revealed in the results was 'innovative efforts of the corporation' $(78 \%)$, which is also notable. Healthcare is an ever-developing industry where improvements in terms of healthcare approaches and techniques occur very frequently, and thus, in this professional service intellect industry (Scott, 1998) where knowledge is exceptional and valuable (Starbuck, 1992), consumers will prefer healthcare facilities adopting most developed medical practices (aligned with the most recent technologies) to receive healthcare. Thus, contribution of this attribute to the overall corporate image is quite substantial. The fourth most favorable public perception revealed in the results was 'well-managed and long-established corporation' (77\%). From the authors' perspective, well-managed and thus long-established corporations will have better prospects in creation of a favorable image, mostly because of their long-lasting existence in the market. This perspective was also reinforced by a study accomplished by Terry and Forrest (2008), in which it is clearly shown how deep-rooted and long-established corporations are advantageous in creating and upholding a corporate image and also securing their brand name in their respective market. The fifth and sixth most favorable public perception revealed in the results were 'attractiveness of employment' $(70 \%)$ and 'corporate social and environmental responsibility' (68\%). Although these two attributes denote meanings, which may not seem interesting or attractive to the general public unless they are directly linked to their daily lives, from the corporate management perspective, it is of great importance to pay considerable attention to these matters as well, because these attributes also play a big role in establishment of a long-standing and sustainable positive corporate image. Considering the increasing knowledge and consciousness on environmental issues throughout the world due to rapidly diminishing resources, "many consumers not only are concerned about the impact that commercial producers have on the environment, but also are willing to pay extra for environmentally benign products" (Balmer \& Gray, 2000). It is thus the authors' belief that the subject healthcare facility should increase its efforts to improve its already-existing public perception specifically in terms of their social and environmental responsibilities by either more effectively reflecting its efforts regarding them on public, or re-formulating their strategies in order to be involved in these types of activities more actively and heavily. With regard to this matter, we also suggest more aggressive corporate management politics applications such as increasing publics' awareness on corporate values and career and individual development opportunities peculiar to the corporation when any type of advertisement and/or information brochures are published. Aside from all other potential benefits it brings to the institution, in an industry such as healthcare where competition is tough, consciousness of institutions about their social and environmental responsibilities and the degree to which these activities are communicated to the members of the public become utterly important in terms of attracting qualified human resources. Because in today's environment, the qualified human resources are not attracted to the corporations solely on the basis of hefty pay packages, but they are more inclined to the corporations whose corporate culture and values, or more broadly, whose corporate images are attractive, and to the corporations in which they will find a lot of themselves, because essentially "a favorable reputation provides a psychological income to the individuals" (Balmer \& Gray, 2000). Though apparently very important, both 'attractiveness of employment' and 'corporate social and environmental responsibility' attributes received the lowest scores, which substantially decreased the subject healthcare facility's overall corporate image scores, hence they deserve special attention. Discussions held with the leadership of the subject healthcare facility revealed that they attributed these two attributes' low scores to some cultural causes, that is, these concepts have yet to be well understood by the public. Our stance as the researchers was that it could have been due to (1) lack of social and environmental practices involvement by the subject hospital, (2) involvement of the subject hospital in these practices were not actively and effectively conveyed to the public, and that (3) some or most of the respondents were unaware of the true meaning of these concepts. More research should be accomplished to clarify this issue and perhaps face-to-face interviews should be performed with an appropriate sample size to get an understanding for whether or not these concepts are clearly understood by the public.

Although this research satisfied all of the authors' pre-identified purposes, it has its limitations. We performed this research with our new model on a sizable sample population to measure corporate image of a healthcare facility in Turkey, but it should be repeated in other research to further validate its reliability and applicability. Further research with confirmatory factor analyses in different data sets are required to re-test the item behavior in the instrument in order to investigate its consistency. Another limitation is that we did not test the concurrent validity of our instrument with other previously established instruments.

Finally, the authors believe that it would be valuable to implement this scale on multiple healthcare facilities in larger areas where there is higher competition in the healthcare sector to evaluate those healthcare facilities' corporate image comparatively. 


\section{References}

Alvesson, M., \& Berg, P. O. (1992). Corporate Culture and Organizational Symbolism. NewYork: Walter de Gruyter. http://dx.doi.org/10.1515/9783110136074

Anderson, C., \& Zeithaml, C. P. (1984). Stage of the product life cycle, business strategy, and business performance. Academy of Management Journal, 27, 5-24. http://dx.doi.org/10.2307/255954

Balmer, J. M. T., \& Gray, E. R. (1999). Corporate identity and corporate communications: Creating a competitive advantage. Corporate Communications: An International Journal, 4(4), 171-176. http://dx.doi.org/10.1108/00197850010379811

Balmer, J. M. T., \& Gray, E. R. (2000). Corporate identity and corporate communications: creating a competitive advantage. Industrial and Commercial Training, 32(7), 256-262. http://dx.doi.org/10.1108/00197850010379811

Barnett, M. L., Jermier, J. M., \& Lafferty, B. A. (2006). Corporate reputation: The definitional landscape. Corporate Reputation Review, 9(1), 26-38. http://dx.doi.org/10.1057/palgrave.crr.1550012

Barnett, M. L., \& Pollock, T. G. (2012). The oxford handbook of corporate reputation. U.K.: The Oxford University Press.

Bartlett, M. S. (1954). A note on the multiplying factors for various chi square approximations. Journal of the Royal Statistical Society, 16(Series B), 296-298.

Baucus, M. S. (1995). Halo-adjusted residuals-Prolonging the life of a terminally ill measure of corporate social performance. Business \& Society, 34, 227-235. http://dx.doi.org/10.1177/000765039503400209

Beatty, R. P. (1989). Auditor reputation and the pricing of initial public offerings. The Accounting Review, 64(4), 693-709.

Belasen, A. T. (2008). The theory and practice of corporate communication: A competing values perspective. California: Sage Publications, Inc.

Berg, P. O. (1985). Organization change as a symbolic transformation process. In P. J. Frost, L. F. Moore, M. R. Louis, C. C. Lundberg, \& J. Martin (Eds.), Organizational culture. Beverly Hills, CA: Sage.

Bernstein, D. (1984). Company image and reality: A critique of corporate communication. London: Holt, Rinehart \& Winston.

Bromley, D. B. (1993). Reputation, image and impression management. Chichester: John Wiley \& Sons.

Bromley, D. B. (2002). Comparing corporate reputations: League tables, quotients, benchmarks or case studies? Corporate Reputation Review, 5(1), 35-50. http://dx.doi.org/10.1057/palgrave.crr.1540163

Burke, R. J., Martin, G., \& Cooper, C. L. (2011). Corporate reputation: Managing opportunities and threats. England: Gower Publishing Limited.

Caruana, A., \& Chircop, S. (2000). Measuring corporate reputation: A case example. Corporate Reputation Review, 3(1), 43-57. http://dx.doi.org/10.1057/palgrave.crr.1540098

Chun, R. (2005). Corporate Reputation: Meaning and measurement. International Journal of Management Reviews, 7(2), 91-109. http://dx.doi.org/10.1111/j.1468-2370.2005.00109.x

Churchill, G. A. Jr. (1979). A paradigm for developing better measures of marketing constructs. Journal of Marketing Research, 16(February), 64-73. http://dx.doi.org/10.2307/3150876

DeVellis, R. F. (2003). Scale development: Theory and applications (2nd ed). Thousand Oaks, California: Sage.

Dhir, K. S., \& Vinen, D. (2005). Managing corporate respectability: Concept, issues, and policy formulation. Corporate Communications: An International Journal, 10(1), 5-23. http://dx.doi.org/10.1108/13563280510578178

Dutton, J. E., \& Dukerich, J. M. (1991). Keeping an eye on the mirror: Image and identity in organizational adaptation. Academy of Management Journal, 34(3), 517-554. http://dx.doi.org/10.2307/256405

Dutton, J. E., Dukerich, J. M., \& Harquail, C. V. (1994). Organizational images and member identification. Administrative Sciences Quarterly, 39(2), 239-263. http://dx.doi.org/10.2307/2393235

Floyd, F. J., \& Widaman, K. F. (1995). Factor analysis in the development and refinement of clinical assessment instruments. Psychological Assessment, 7(3), 286-299. http://dx.doi.org/10.1037/1040-3590.7.3.286 
Fombrun, C. J. (1996). Reputation: Realizing value from corporate image. Boston, MA: Harvard Business School Press.

Fombrun, C., \& Shanley, M. (1990). What's in a name? Reputation building and corporate strategy. Academy of Management Journal, 33(2), 233-258. http://dx.doi.org/10.2307/256324

Fombrun, C. J., \& van Riel, C. B. M. (1997). The reputational landscape. Corporate Reputation Review, 1(1/2), 6-13. http://dx.doi.org/10.1057/palgrave.crr.1540008

Fryxell, G. E., \& Wang, J. (1994). The Fortune corporate 'Reputation' index: Reputation for what? Journal of Management, 20, 1-14. http://dx.doi.org/10.1177/014920639402000101

Garvin, D. A. (1983). Quality on the line. Harvard Business Review, 61, 65-73.

Gorsuch, R. L. (1983). Factor analysis (2nd ed.). New Jersey: Erlbaum.

Gotsi, M., \& Wilson, A. M. (2001). Corporate reputation: Seeking a definition. Corporate Communications: An International Journal, 6(1), 24-30. http://dx.doi.org/10.1108/13563280110381189

Gray, E. R., \& Balmer, J. M. T. (1998). Managing corporate image and reputation. Long Range Planning, 31(5), 695-702. http://dx.doi.org/10.1016/S0024-6301(98)00074-0

Greenwood, R., Li, S. X., Prakash, R., \& Deephouse, D. L. (2005). Reputation, diversification, and organizational explanations of performance in professional service firms. Organization Science, 16(6), 661-673. http://dx.doi.org/10.1287/orsc.1050.0159

Hair, J. F., Anderson, R. E., Tatham, R. L., \& Black, W. C. (1998). Multivariate data analysis (5th ed.). New Jersey: Prentice Hall.

Hatch, M. J., \& Schultz, M. (1997). Relations between organizational culture, identity and image. European Journal of Marketing, 31(5/5), 356-365. http://dx.doi.org/10.1108/eb060636

Kaiser, H. (1974). An index of factorial simplicity. Psychometrika, 39, 31-36. http://dx.doi.org/10.1007/BF02291575

Krejcie, R. V., \& Morgan, D. W. (1970). Determining sample size for research activities. Educational and Psychological Measurement, 30, 607-610. http://dx.doi.org/10.1177/001316447003000308

Krishnan, J., \& Schauer, P. C. (2000). The differentiation of quality among auditors: Evidence from the not-for-profit sector. Auditing, 19(2), 9-25. http://dx.doi.org/10.2308/aud.2000.19.2.9

Lowendahl, B. (2000). Strategic Management of Professional Firms (2nd ed.). Copenhag, Denmark: Handelshojskolens Forlag.

Maister, D. H. (1993). Managing the professional service firm. New York: The Free Press.

Melewar, T. C. (2003). Determinants of the corporate identity construct. Journal of Marketing Communications, 9, 195-220. http://dx.doi.org/10.1080/1352726032000119161

Nunnally, J. O. (1978). Psychometric theory. New York: McGraw-Hill.

Pallant, J. (2010). SPSS survival manual: A step by step guide to data analysis using the SPSS program (4th ed.). New York: Open University Press.

Parasuraman, A., Zeithaml, V. A., \& Berry, L. L. (1985). A conceptual model of service quality and its implications for future research. Journal of Marketing, 49, 41-50. http://dx.doi.org/10.2307/1251430

Peter, J. P. (1981). Costruct validity: A review of basic issues and marketing practices. Journal of Marketing Research, 18(May), 133-145. http://dx.doi.org/10.2307/3150948

Phillips, L. W., Chang, D. R., \& Buzzell, R. D. (1983). Product quality, cost position and business performance: A test of some key hypotheses. Journal of Marketing, 47, 26 -43. http://dx.doi.org/10.2307/1251491

Rindell, A., Edvardsson, B., \& Strandvik, T. (2010). Mapping the roots of the consumer's image-in-use of companies. Journal of Product \& Brand Management, 19(6), 423-431. http://dx.doi.org/10.1108/10610421011085730

Scott, M. C. (1998). The intellect industry: Profiting and learning from professional service firms. New York: John Wiley \& Sons.

Sodeman, W. A. (1995). Advantages and disadvantages of using the Brown and Perry database. Business \& Society, 34, 216-221. http://dx.doi.org/101177/000765039503400207 
Starbuck, W. H. (1992). Learning by knowledge-intensive firms. Journal of Management Studies, 29(4), 713-740. http://dx.doi.org/10.1111/j.1467-6486.1992.tb00686.x

Streiner, D. L. (1994). Figuring out factors: The use and misuse of factor analysis. Canadian Journal of Psychiatry, 39, 135-140.

Tabachnick, B. G., \& Fidell, L. S. (2007). Using multivariate statistics (5th ed.). Boston: Pearson Education.

Terry, A., \& Forrest, H. (2008). Where is the beef? Why Budger King is Hungry Jack's in Australia and other complications in building a global franchise brand. Northwestern Journal of International Law \& Business, 28(2), 171-213.

Wartick, S. L. (2002). Measuring corporate reputation: Definition and data. Business \& Society, 41(4), 371-393. http://dx.doi.org/10.1177/0007650302238774

Wei, Y. K. (2002). Corporate image as collect ethos: A poststructuralist approach. Corporate Communications: An International Journal, 7(4), 269-278. http://dx.doi.org/10.1108/13563280210449859

Weigelt, K., \& Camerer, C. (1988). Reputation and corporate strategy: A review of recent theory and applications. Strategic Management Journal, 9, 443-454. http://dx.doi.org/10.1002/smj.4250090505

Whetten, D. A., Lewis, D., \& Mischel, L. J. (1992). Towards an integrated model of organizational identity and member commitment. Paper presented at the Academy of Management, Las Vegas, NV.

Whetten, D. A., \& Mackey, A. (2002). A social actor conception of organizational identity and its implications for the study of organizational reputation. Business and Society, 41(4), 393-414. http://dx.doi.org/10.1177/0007650302238775

Williams, R. J., \& Barrett, J. D. (2000). Corporate philanthropy, criminal activity and firm reputation: Is there a link? Journal of Business Ethics, 26, 341-350. http://dx.doi.org/10.2307/25074351

\section{Copyrights}

Copyright for this article is retained by the author(s), with first publication rights granted to the journal.

This is an open-access article distributed under the terms and conditions of the Creative Commons Attribution license (http://creativecommons.org/licenses/by/3.0/). 